\title{
BRPKM
}
Buletin Riset Psikologi dan Kesehatan Mental http://e-journal.unair.ac.id/index.php/BRPKM e-ISSN: 2776-1851

ARTIKEL PENELITIAN

\section{Hubungan antara Konsep diri dengan Kecenderungan Menjadi Korban Kekerasan dalam Pacaran Pada Wanita}

\author{
HASHINTA MEIDINDA ECHAPUTRI \& IKE HERDIANA* \\ Fakultas Psikologi Universitas Airlangga
}

\begin{abstract}
ABSTRAK
Penelitian ini bertujuan untuk mengetahui hubungan antara konsep diri dengan kecenderungan menjadi korban kekerasan dalam pacaran pada wanita di Surabaya. Peneliti menggunakan pendekatan kuantitatif dengan metode penelitian survei. Populasi penelitian ini adalah wanita yang bertempat tinggal di Surabaya dengan usia 18-25 tahun dan sedang berada dalam hubungan berpacaran. Metode pengambilan sampel menggunakan teknik accidental sampling dengan jumlah sampel 75 orang. Pengambilan data dilakukan dengan menggunakan alat ukur konsep diri dan kekerasan dalam pacaran. Hasil analisis penelitian ini adalah adanya hubungan negatif antara konsep diri dan kecenderungan menjadi korban kekerasan dalam pacaran pada wanita di Surabaya, dimana apabila nilai konsep diri seseorang menurun, maka kecenderungannya menjadi korban kekerasan dalam pacaran meningkat, begitu pula sebaliknya.
\end{abstract}

Kata kunci: kekerasan dalam pacaran, konsep diri, Surabaya

\begin{abstract}
This study aims to analyze correlation between self-concept and tendency to become dating violence victims on women in Surabaya. This research is qualitative research with survey method. Population of this study is women who lives in Surabaya within the age of 18-25 years old and currently in relationship. Sampling method that was used for this study is convenience sampling with the sample size 75 women. Data were collected using two measuring instruments; self-concept scale and dating violence scale. The results show that self-concept has medium correlation with tendency to become dating violence victims, in opposites directions. This means the higher someone's self-concept is, the lower tendency that they have to become dating violence victims.
\end{abstract}

\section{Keywords: dating violence, self-concept, Surabaya}

Buletin Penelitian Psikologi dan Kesehatan Mental (BRPKM), 2021, Vol. 1(1), 663-669

*Alamat korespondensi: Fakultas Psikologi Universitas Airlangga, Kampus B Universitas Airlangga Jalan Airlangga 4-6 Surabaya 60286. Surel: ike.herdiana@psikologi.unair.ac.id

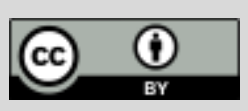

Naskah ini merupakan naskah dengan akses terbuka dibawah ketentuan the Creative Common Attribution License (CC-BY-4.0) (http://creativecommons.org/licenses/by/4.0), sehingga penggunaan, distribusi, reproduksi dalam media apapun atas artikel ini tidak dibatasi, selama sumber aslinya disitir dengan baik. 


\section{PENDAHULUAN}

Dalam perkembangan manusia menurut Erikson (Papalia dkk., 2009), apabila manusia mulai memasuki usia dewasa awal, mereka ada dalam tahap intimacy vs isolation. Hal yang dimaksud dari itu adalah apabila manusia berada pada usia dewasa awal, perkembangan mereka akan berfokus pada membentuk hubungan-hubungan yang dekat seperti pertemanan, pacaran, atau bahkan pernikahan. Apabila mereka berhasil melakukannya, mereka akan memiliki hubungan yang kuat. Jika mereka gagal melakukannya, mereka akan merasa terkucilkan. Hubungan berpacaran menurut Wardani \& Setyanawati (2014) adalah serangkaian dari aktivitas yang dilakukan bersama oleh laki-laki dan perempuan yang belum terikat dalam ikatan perkawinan diwarnai oleh keintiman (adanya rasa kepemilikan dan keterbukaan diri) serta juga adanya keterikatan emosi antara keduanya dengan tujuan untuk saling mengenal dan melihat kecocokan mereka sebelum akhirnya memutuskan untuk menikah.

Kekerasan dalam pacaran adalah tindakan dengan unsur kesengajaan yang dilakukan dengan cara melukai salah satu pihak dan terdapat unsur paksaan fisik dengan tujuan mendapatkan dan mempertahankan kontrol yang dimiliki terhadap pasangannya (Murray, 2001). Menurut Murray (2001), terdapat 3 bentuk kekerasan dalam pacaran yaitu, kekerasan fisik, kekerasan verbal dan emosional, dan kekerasan seksual.

Dalam Catatan Kekerasan Terhadap Perempuan Tahun 2019 yang dikeluarkan oleh Komisi Anti Kekerasan Terhadap Perempuan atau Komnas Perempuan, kasus kekerasan terhadap perempuan pada tahun 2019 adalah sebanyak 431.471 kasus. Angka ini memiliki arti bahwa kekerasan terhadap perempuan meningkat sebanyak delapan kali lipat atau 800\% semenjak tahun 2008 (Komnas Perempuan, 2020a). Bahkan berdasarkan artikel dari Jurnal Perempuan (2021), menurut Catatan Tahunan Komnas Perempuan Tahun 2021, jumlah pengaduan kasus kekerasan terhadap perempuan naik drastis yaitu sebanyak 60\% semenjak 2019 ke 2020 (Komalasari, 2021). Untuk kasus kekerasan dalam pacaran sendiri memang mengalami penurunan dari tahun sebelumnya yang berjumlah 2.073 menjadi 1.815 kasus. Walaupun mengalami penurunan, kasus kekerasan dalam pacaran tetap menjadi kasus terbanyak setelah kekerasan terhadap istri. Pada tahun 2019, Komnas Perempuan juga mencatat bahwa pelaku kekerasan dalam ranah personal terbanyak adalah pacar. Komnas Perempuan juga menyatakan angka tersebut bisa lebih banyak dilapangan dikarenakan adanya kemungkinan bahwa korban kekerasan dalam pacaran tersebut memilih untuk bertahan dan tidak melaporkan perilaku kekerasan yang dialaminya (Komnas Perempuan, 2020).

Kekerasan dalam pacaran ini adalah perilaku yang sering dijumpai di kota-kota besar seperti Jakarta dan Yogyakarta, di daerah yang rawan kemiskinan dan banyak terjadi konflik, serta daerah yang memiliki perekonomian dan kebudayaan yang dinamis seperti Surabaya dan Sulawesi Selatan (Widjanarko \& Khaninah, 2016). Savy Amira merupakan lembaga non-profit yang didirikan oleh beberapa aktivis perempuan yang berbasis di Surabaya. Lembaga ini membuat Catatan Tahunan 2019 yang berisi kasus-kasus kekerasan terhadap perempuan yang terjadi di Surabaya dan sekitarnya. Berdasarkan Catatan Tahunan tersebut, Savy Amira menyatakan bahwa mayoritas kasus berasal dari Kota Surabaya dengan kasus terbanyak adalah kasus kekerasan dalam pacaran yang disusul oleh kekerasan terhadap istri (Savy Amira, 2019).

Terdapat beberapa faktor yang menyebabkan terjadinya kekerasan dalam pacaran ini. Menurut Dardis dkk (2015), faktor-faktor yang mendasari terjadinya kekerasan dalam pacaran adalah historical variable, personal variable, interpersonal variable, dan contextual variable. Historical variable memiliki arti yaitu apabila seseorang terpapar oleh kekerasan interparental, kekerasan pada anak, atau 
kenakalan remaja, akan tinggi kemungkinannya melakukan kekerasan dalam pacaran. Sebaliknya, personal variable adalah apabila seseorang sedang berada dalam tekanan psikologis, menyalahgunakan narkotika dan obat-obatan terlarang, dan memiliki suatu pandangan yang negatif terhadap gender, maka akan tinggi kemungkinan mereka melakukan kekerasan dalam pacaran. Interpersonal variable bisa dalam bentuk kekerasan bidirectional couple dan masalah dalam mengontrol amarah. Contextual variable adalah adanya pengaruh dari rekan sebaya dan motivasi berupa amarah, cemburu, dan keinginan mengontrol (Dardis dkk., 2015).

Wijaya (2019) melakukan penelitian untuk melihat hubungan antara sumber informasi, peran keluarga, pengetahuan, dan konsep diri terhadap pencegahan kekerasan dalam pacaran. Pada penelitian ini dijelaskan bahwa konsep diri merupakan salah satu faktor dominan yang membantu pencegahan kekerasan dalam pacaran karena individu yang memiliki nilai konsep diri yang tinggi akan menghargai dirinya sendiri dan juga orang lain sehingga mencegah terjadinya kekerasan dalam pacaran (Wijaya, 2019). Beberapa penelitian lainnya menjelaskan faktor-faktor yang memengaruhi kecenderungan seseorang menjadi korban kekerasan dalam pacaran. Pada penelitian yang dilakukan oleh Taylor, Wamser, Welch, dan Nanney (2012), partisipasi perempuan dalam olahraga mampu menurunkan kecenderungannya menjadi korban kekerasan dalam pacaran. Hal ini disebabkan oleh meningkatnya rasa kepercayaan diri pada perempuan yang berpartisipasi dalam olahraga (Taylor dkk., 2012). Hanoum dan Muslimah (2017) juga melakukan penelitian untuk melihat bagaimana hubungan konsep diri dan peer group terhadap kecenderungan menjadi korban kekerasan dalam pacaran. Hasil penelitian itu menyatakan bahwa terdapat hubungan searah antara konsep diri dengan peer group dan hubungan berlawanan arah antara konsep diri dengan kecenderungan menjadi korban kekerasan dalam pacaran. Menurut Hanoum dan Muslimah (2017), hal ini disebabkan apabila seseorang memiliki nilai konsep diri yang tinggi, orang tersebut akan menghargai dirinya dan orang lain sehingga memiliki peer group yang positif. Maka dari itu, orang tersebut tidak akan membiarkan adanya tindakan kekerasan terhadap dirinya (Hanoum \& Muslimah, 2017).

Konsep diri menurut William H. Fitts (Agustiani, 2006) adalah aspek yang berada di dalam diri manusia yang berguna sebagai kerangka acuan atau frame of reference seseorang untuk berinteraksi dengan lingkungannya. Menurut Fitts (Agustiani, 2006), terdapat dua dimensi dari konsep diri yaitu dimensi internal dan eksternal. Aspek yang meliputi dimensi internal yaitu identity self, behavioral self, dan judging self. Identity self adalah bagaimana individu tersebut menggambarkan dirinya sendiri. Behavioral self adalah aspek yang berhubungan dengan tingkah laku individu itu sendiri. Judging self adalah bagaimana seseorang menilai dirinya. Sedangkan yang meliputi dimensi eksternal adalah physical self, moral self, personal self, family self, dan social self. Physical self adalah aspek yang berkaitan dengan penilaian seseorang mengenai fisiknya. Moral-ethical self atau diri etik moral ini aspek yang berhubungan dengan penilaian diri seseorang berdasarkan moral, etika, dan aspek religiusitas yang ia pegang. Personal self adalah penilaian individu terhadap nilai-nilai dirinya terlepas dari keadaan fisiknya dan kehidupan sosialnya. Family self adalah aspek yang berkaitan dengan hubungan individu dengan keluarganya. Social self adalah aspek yang berkaitan dengan bagaimana penilaian individu terhadap interaksinya dengan lingkungan sosialnya.

Seperti yang telah dijelaskan sebelumnya, kekerasan terhadap wanita memiliki angka yang tinggi bahkan pada tahun 2019 telah meningkat sebanyak 800\% dibandingkan dengan tahun 2008, dimana pelaku kekerasan menurut Komnas Perempuan didominasi oleh pacar dari korban. Temuan ini juga didukung oleh temuan Savy Amira bahwa di kota Surabaya, kekerasan terhadap pacar memiliki angka lebih tinggi dibandingkan dengan kekerasan terhadap istri. Korban kekerasan terhadap ini juga paling 
banyak wanita yang ada di dalam usia dewasa awal, pendidikan terakhir SMA dan berprofesi sebagai pelajar. Banyaknya kasus kekerasan terhadap wanita khususnya pada hubungan berpacaran maka peneliti tertarik untuk meneliti faktor yang berhubungan dengan kecenderungan menjadi korban kekerasan dalam pacaran.

Peneliti memilih konsep diri sebagai faktor yang berhubungan dengan kecenderungan menjadi korban kekerasan dalam pacaran dikarenakan pada penelitian yang telah dilakukan oleh Hanoum \& Muslimah yang menyatakan bahwa nilai konsep diri yang tinggi mampu menurunkan kecenderungan seseorang menjadi korban kekerasan dalam pacaran. Hal ini dikarenakan individu yang memiliki nilai konsep diri yang rendah mampu menghargai dirinya dan orang lain dengan baik, sehingga tidak akan membiarkan apabila dirinya diperlakukan dengan tidak baik oleh orang lain (Hanoum \& Muslimah, 2017).

Rumusan masalah pada penelitian ini mengenai hubungan antara konsep diri dengan kecenderungan menjadi korban kekerasan dalam pacaran. Tujuan dari penelitian ini adalah untuk mengetahui ada atau tidaknya hubungan antara konsep diri dengan kecenderungan menjadi korban kekerasan dalam pacaran dan mengetahui bagaimana hubungan antara konsep diri dengan kecenderungan menjadi korban kekerasan dalam pacaran. $\mathrm{H} 0$ dalam penelitian ini adalah tidak adanya hubungan antara konsep diri dengan kecenderungan kekerasan dalam pacaran, sedangkan Ha adalah adanya hubungan antara konsep diri dengan kecenderungan kekerasan dalam pacaran.

\section{Desain Penelitian}

\section{METODE}

Penelitian ini menggunakan pendekatan kuantitatif dengan metode penelitian survei korelasional. Hal ini dikarenakan penelitian ini bertujuan untuk mencari hubungan antara dua variabel yaitu variabel konsep diri dengan kecenderungan menjadi korban kekerasan dalam pacaran. Variabel (X) atau variabel bebas dari penelitian ini adalah konsep diri, sedangkan variabel (Y) atau variabel terikat pada penelitian ini adalah kecenderungan menjadi korban kekerasan dalam pacaran. Teknik pengumpulan data yang digunakan peneliti adalah teknik pengumpulan data survei dengan alat ukur kuesioner yang berbentuk self-report. Alat ukur yang digunakan oleh peneliti pada penelitian ini adalah alat ukur konsep diri yang dikembangkan oleh Erin A. Fitri pada tahun 2017 dan alat ukur kekerasan dalam pacaran yang dikembangkan oleh Dendy Setyadi pada tahun 2013. Teknik analisis data menggunakan uji korelasi dengan program pengolah data IBM SPSS 25.0 for Windows.

\section{Partisipan}

Partisipan penelitian adalah wanita yang bertempat tinggal di Surabaya dengan usia 18-25 tahun yang sedang berada di dalam hubungan berpacaran. Metode pengambilan sampel pada penelitian ini adalah menggunakan metode non-probability sampling dengan teknik accidental sampling dengan jumlah sampel sebanyak 75 orang. Partisipan diberikan informed consent sebelum mengisi kuesioner.

Peneliti melibatkan 75 orang dengan perempuan berusia 22 tahun yang sebanyak 25 orang atau 33,3\%. Berdasarkan usia hubungannya, partisipan paling banyak sudah berpacaran selama lebih dari 2 tahun yaitu sebanyak 30 orang (40,0\%). Sedangkan yang paling sedikit sudah berpacaran selama kurang dari 6 bulan yaitu sebanyak 10 orang (13,3\%). Rata-rata usia partisipan adalah 20,933 dan standar deviasinya $1,46$. 


\section{Pengukuran}

Pengukuran variabel konsep diri pada penelitian ini menggunakan alat ukur konsep diri yang dikembangkan oleh Fitri ( 2017). Alat ukur ini didasari dari teori konsep diri menurut William H. Fitts. Hasil uji reliabilitas alat tes ini adalah tinggi (30 aitem, $\alpha=.922$ ). Alat tes ini berupa skala yang terdiri dari 4 pilihan jawaban (1= "sangat tidak setuju", 4="sangat setuju"). Untuk mengukur kecenderungan menjadi korban kekerasan dalam pacaran, peneliti menggunakan alat ukur yang dikembangkan oleh Dendy Setyadi (Setyadi, 2013), yang terdiri dari 58 aitem dengan 4 pilihan jawaban (1= "dilakukan 1-3 kali", 2= "dilakukan 4-7 kali", 3= "dilakukan 8-10 kali", 4= "dilakukan lebih dari 10 kali") dengan reliabilitas alat ukur ini sangat tinggi $(\alpha=.992)$.

Hasil skor kemudian didapatkan dengan cara dijumlah. Uji asumsi yang dilakukan oleh peneliti adalah uji normalitas untuk melihat apakah data yang diperoleh berdistribusi normal. Uji normalitas dilakukan dengan menggunakan Kolmogorov-Smirnov yang menunjukan hasil residual sebesar 0.2. Dikarenakan hasil residual lebih dari 0.05 maka data dinyatakan berdistribusi normal.

\section{Analisis Data}

Analisis data yang dilakukan oleh peneliti adalah dengan melihat pearson correlation dari konsep diri dan kecenderungan menjadi korban kekerasan dalam pacaran. Seluruh uji analisis data yang dilakukan pada penelitian ini menggunakan SPSS 25.0 for Windows.

\section{HASIL PENELITIAN}

Pada kategorisasi variabel konsep diri, terdapat 10 orang dalam kategori rendah (13,3\%). Sedangkan pada kategori sedang sebanyak 50 orang $(66,7 \%)$. Pada kategori tinggi sebanyak 15 orang $(20,0 \%)$. Pada kategorisasi variabel kecenderungan menjadi korban kekerasan dalam pacaran, kategori rendah terdapat 7 orang $(9,3 \%)$. Sedangkan dalam kategori sedang dan tinggi sebanyak 57 orang (76,0\%) dan 11 orang $(14,7 \%)$. Berdasarkan hasil uji korelasi, didapatkan bahwa konsep diri berkorelasi negatif dan cenderung sedang dengan kecenderungan menjadi korban kekerasan dalam pacaran $(r(75)=-0,386$, $p=0,001)$.

\section{DISKUSI}

Hasil uji korelasi yang dilakukan memperlihatkan bahwa nilai koefisiensi antara variabel konsep diri dan kecenderungan menjadi korban kekerasan dalam pacaran adalah sebesar -0,387. Hal ini dapat dikatakan bahwa terdapat hubungan yang signifikan yang bersifat negatif dengan kekuatan sedang antara kedua variabel. Hubungan negatif memiliki arti bahwa apabila nilai konsep diri seseorang meninggi, maka kecenderungan orang tersebut untuk menjadi korban kekerasan dalam pacaran pun menurun. Begitu pula dengan nilai konsep diri seseorang menurun, berarti kecenderungannya untuk menjadi korban kekerasan dalam pacaran meninggi.

Hasil penelitian ini sesuai dengan penelitian yang dilakukan oleh Hanoum dan Muslimah (2017), orangorang dengan nilai konsep diri yang tinggi akan memiliki sikap yang percaya diri. Seseorang akan menghargai dirinya sendiri dengan tidak membiarkan orang lain yang tidak memperlakukan dirinya dengan baik. Oleh karena itu, orang-orang dengan nilai konsep diri tinggi akan menjauhi pasangannya

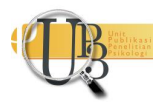


apabila pasangannya melakukan kekerasan terhadap dirinya. Sebaliknya, orang-orang dengan konsep diri negatif akan membiarkan apabila tidak diperlakukan dengan baik karena dia memiliki pandangan yang buruk terhadap dirinya (Hanoum \& Muslimah, 2017).

Terdapat faktor-faktor lain yang dapat memengaruhi kecenderungan seseorang menjadi korban kekerasan dalam pacaran. Penelitian yang dilakukan oleh Taylor, Wamser, Welch, dan Nanney (2012) menyatakan bahwa perempuan yang berpartisipasi dalam olahraga mampu menurunkan kecenderungannya menjadi korban kekerasan secara general dan kekerasan oleh pasangan (Taylor dkk., 2012). Hal ini dikarenakan partisipasi olahraga menambah kepercaya dirian perempuan yang kemudian membuat kecenderungannya untuk menjadi korban ikut menurun. Penelitian yang dilakukan oleh Wijaya (2019) bahwa faktor lain seperti sumber informasi, peran keluarga, pengetahuan, dan konsep diri mampu menjadi faktor pencegahan kekerasan dalam pacaran (Wijaya, 2019).

\section{SIMPULAN}

Berdasarkan hasil analisis data yang telah dilakukan oleh peneliti, dapat disimpulkan bahwa terdapat hubungan antara konsep diri dengan kecenderungan menjadi korban kekerasan dalam pacaran. Hubungan antara konsep diri dengan kecenderungan menjadi korban kekerasan dalam pacaran ini bersifat negatif dimana apabila nilai konsep diri seseorang menurun, maka kecenderungan seseorang untuk menjadi korban kekerasan dalam pacaran akan meningkat, begitu pula sebaliknya.

Saran untuk penelitian selanjutnya adalah diharapkan untuk melengkapi penelitian ini dengan menambah jumlah sampel dari wilayah Indonesia yang lainnya sehingga generalisasi hasil penelitian lebih terwakili.

\section{U C A P A N T ERIMAKASIH}

Terima kasih penulis ucapkan kepada Allah SWT, keluarga penulis, dosen pembimbing saya, dan temanteman penulis yang turut membantu dan mendukung penulis selama melakukan penelitian ini.

\section{DEKLARASI POTENSI TERJADINYA KONFLIK KEPENTINGAN}

Hashinta Meidinda Echaputri dan Ike Herdiana tidak bekerja, menjadi konsultan, memiliki saham, atau menerima dana dari perusahaan atau organisasi manapun yang mungkin akan mengambil untung dari diterbitkannya naskah ini.

\section{PUSTAKA ACUAN}

Agustiani, H. (2006). Psikologi Perkembangan: Pendekatan Ekologi Kaitannya dengan Konsep diri dan Penyesuaian Diri Pada Remaja. Refika Aditama.

Dardis, C., Dixon, K. J., Edwards, K. M., \& Turchik, J. A. (2015). An examination of the factors related to dating violence perpetration among young men and women and associated theoretical explanations: A review of the literature. Trauma, Violence, \& Abuse, 136-152. https://doi.org/10.1177/1524838013517559

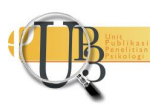


Fitri, E. A. (2017). Hubungan Antara Konsep Diri dengan Penerimaan Diri Siswa Kelas VII SMPN 3 Bandung Tulungagung. Undergraduate Thesis, Universitas Islam Negeri Maulana Malik Ibrahim.

Hanoum, M., \& Muslimah, A. I. (2017). Konsep Diri, Peer Group, dan Kecenderungan Menjadi Korban Kekerasan dalam Pacaran. SOUL, 9(1), 13-21.

Komalasari, D. (2021, March 3). CATAHU 2021 Komnas Perempuan: Kekerasan Terhadap Perempuan dan Dispensasi Perkawinan Melonjak Selama Pandemi. Jurnal Perempuan. http://www.jurnalperempuan.org/warta-feminis/catahu-2021-komnas-perempuankekerasan-terhadap-perempuan-dan-dispensasi-perkawinan-melonjak-selamapandemi\#: :text=CATAHU\%202021\%20mencatat\%20sejumlah\%20299.911,yang\%20mencat at\%20sebanyak\%20431.471\%20kasus

Komnas Perempuan. (2020a). Catatan Kekerasan Terhadap Perempuan Tahun 2019.

Murray, J. (2001). But I love him: Protecting your teen daughter from controlling, abusive dating relationships. Harper Collin Publisher.

Papalia, D., Old, S. W., \& Feldman, R. D. (2009). Human Development Perkembangan Manusia. Salemba Humanika.

Savy Amira. (2019). Catatan Tahunan Savy Amira 2019. http://www.savyamirawcc.com/tentangkami/laporan/catahu/

Setyadi, D. (2013). Kekerasan dalam pacaran: Studi deskriptif pada siswa kelas XI SMA N 1 Karangnongko tahun ajaran 2012/2013 dan implikasinya terhadap usulan topik-topik layanan bimbingan pribadi sosial. Skripsi Thesis, Sanata Dharma University.

Taylor, M. J., Wamser, R., Welch, D. Z., \& Nanney, J. (2012). Multidimensional Self-Esteem as a Mediator of the Relationship Between Sports Participation and Victimization: A Study of African American Girls. Violence and Victims, 434-452. https://doi.org/10.1891/0886-6708.27.3.434

Wardani, D. P., \& Setyanawati, Y. (2014). Tinjauan Viktimologi dan Perlindungan Hukum Korban Kekerasan Dalam Pacaran. Jurnal Serambu Hukum, 4-5.

Widjanarko, M., \& Khaninah, A. N. (2016). Perilaku Agresif yang Dialami Korban Kekerasan dalam Pacaran. Jurnal Psikologi Undip, 151-160. https://doi.org/10.14710/jpu.15.2.151-160

Wijaya, P. (2019). Sumber Informasi, Peran Keluarga, Pengetahuan dan Konsep Diri Terhadap Perilaku Pencegahan Kekerasan Dalam Berpacaran. JEN (JOURNAL EDUCATIONAL OF NURSING), 95-109. https://doi.org/10.37430/jen.v2i1.15 